\title{
Description of seed and pollen micromorphology and their taxonomic impact in some Solanum L. species
}

\author{
Mayada Mahdy ${ }^{*}$, Rim Hamdy ${ }^{2}$ Loutfy M. Hasan ${ }^{1}$ and Abdelfattah Badr ${ }^{1}$
}

${ }^{1}$ Botany and Microbiology Department, Faculty of Science, Helwan University, Cairo, Egypt

${ }^{2}$ Botany and Microbiology Department, Faculty of Science, Cairo University, Giza, Egypt

*Corresponding author: mayada.mahdy21@yahoo.com

\begin{abstract}
Seed micromorphology, of 17 species and pollen micro-morphology of 16 species of Solanum L. (Solanaceae) were examined using both light and scanning electron microscopy (SEM) to determine the significance of seed coat features and pollen variations as taxonomic characters. The species, used in this study, represent three subgenera and 11 sections of Solanum in Egypt. Macro and micro-morphological characters including seed shape, size, colour, surface; hilum shape, size, position, level; seed coat ornamentation, cell wall; shape of pollen in both polar and equatorial views, colpus membrane and apices beside exine ornamentation have been described and their taxonomic impacts have been outlined. Seed shape was either obovate or reniform and their sizes range between $1.22 \pm 0.19$ and $3.05 \pm 0.91 \mathrm{~mm}$ in length and $1.14 \pm 0.21$ to $3.28 \pm 0.63 \mathrm{~mm}$ in diameter. Four types of seed coat appearance have been described: reticulate, cerebelloid, striate and without conspicuous cell lumen. Palynological study revealed six types of pollen shape within the studied species: prolate, subprolate, spheroidal, prolatespheroidal, oblate-spheroidal and perprolate. Pollen length in polar view ranged from $15 \pm 0.50 \mu \mathrm{m}$ to $34 \pm 2 \mu \mathrm{m}$ but in the equatorial view it ranged from $9.06 \pm 1.94 \mu \mathrm{m}$ to $25 \pm 2 \mu \mathrm{m}$. Four types of exine ornamentation have been recognized: scabrate, psilate, granulate and verrucate. Nineteen characters of seed and pollen micromorphological features gave useful tools in the construction of a dichotomus indented systematic key for the examined species. The major remarks are the differentiation of by their reniform seed shape from the remaining species which have ovoid seed shape. Seed coat sculpture and pollen grain feature were useful traits for the identification of the other nine taxa.
\end{abstract}

Keywords: Pollen grains, seed morphology, SEM, Solanum species, taxonomy

\section{Introduction}

Seeds provide major morphological macro and micro-structures for the distinction between various plant species and higher taxonomic ranks (Barthlott 1981 \& 1984). Studies on the Solanaceae have shown that the seed micro-morphology and epidermal patterns are of considerable systematic importance at tribal level in Hyoscyameae (Zhang et al. 2005) and subtribal level in Hyoscyamine (Lu \& Zhang 1986); sectional level (Edmonds 1983) and generic and specific levels. Characters of the seed coat were used to distinguish species in the genera Physalis L., Capsicum L., Tubacapsicum (Wettst.) Makino (Zhang \& Wen 1996; Zhang \& Lu 1999), and in Nicotiana (Bahadur \& Farooqui 1986), Schwenckia (Carvalho et al. 1999), Withania somnifera (Ghimire et al. 2011)) and cultivars of Lycopersicon esculentum (Chakrabarti et al. 2003). The taxonomic importance of seed characters of Solanum has been emphasized by a number of authors, e.g. Lester (1991), and
Junlakitjawat et al. (2010). Khafagy et al. (2018) used 20 fruit and seed characters for the construction of a dichotomous key for 24 species of the family Solanaceae. Ahmed \& Fadl (2016) used seed coat morphology for the investigation of the relationships among seven Solanum L. species collected from Taif highlands in Saudi Arabia. Scanning electron microscope (SEM) investigation of seed coat sculpturing showed three basic patterns, namely; regulate, reticulate and lavigate.

Pollen grain morphology has been found of fundamental value in the recognition and identification of pollen grains found in various conditions (Arora \& Modi 2008). The pollen wall has been a subject of considerable attention, especially in attempts to establish the evolutionary history of angiosperms (Singh, 2006). The pollen morphology of Solanaceae had been a subject of interest for various researchers from time to time (Perveen \& Qaiser, 2007). Bradley (1960) examined the 


\section{Description of seed and pollen micromorphology}

pollen surfaces of Solanum nigrum and $S$. dulcamara by SEM, S. nigrum pollen was described as regularly papillate while $S$. dulcamara was irregularly papillate with nonapertural exine in both taxa. A light and SEM study of the pollen of 16 taxa of Solanum, section Basarthrum by Anderson \& Gensel (1976) revealed differences in exine characters and size amounting to taxa distinctions. Edmonds (1984) confirmed the spheroidal to subprolate shape of pollen morphology in Solanum section Solanum using SEM, their tricolporate shape and granular surface sculpturing, typical of Solanum pollen, but failed to demonstrate the occurrence of exine patterns which could be of practical taxonomic use in differentiating the species in section Solanum. More investigations on the palynomorphs of genus Solanum were made by Sharma (1974) and Lashin (2012). However, El-Ghamery et al. (2018) confirmed a homogeneous morphological pattern to the pollen grains of the genus Solanum.

The genus Solanum comprises about 1500 species, widely distributed in the temperate and tropical regions of the world (Jennifer \& James, 1997). Several works dealt with the species of Solanum in Egypt the number of species were 33 in Hepper (1998) and nine in Boulos (2002). The aim of this work is to analyse the seed coat and pollen macro and micro-morphological features as revealed by light microscopy (LM) and scanning electron microscopy (SEM) to evaluate the taxonomic impact of their features on the systematic of 17 species of Solanum growing in Egypt.

\section{Material and Methods}

The present investigation is based on some freshly collected seeds and pollen, of most species or taken from herbarium collections kept at Cairo University Herbarium (CAI). Localities and collectors of samples are given in Table 1. Fresh mature seeds and flowers were collected of $S$. abutiloides, $S$. diphyllum, S. elaeagnifolium, S. laciniatum, S. lycopersicum, S. macrocarpon, S. melongena, S. nigrum, S. sinaicum, S. umbellatum and S. villosum during 2016-2017 while seeds and pollen of $S$. incanum, S. schimperianum, $S$. coagulans, $S$. forskalii, $S$. seaforthianum and $S$. virginianum were taken from herbarium collections kept in Cairo University Herbarium (CAI).

Seed preparation for SEM was done by removing seeds from fruit pulp prior to cleaning in running tap water and air drying. The dried seeds were carefully fixed to labeled double-sided adhesive tape. Each sample was coated with gold in a Polaron E 5000 and examined by JEOL JSM scanning electron microscopy accelerated by a voltage of $15 \mathrm{kv}$ at SEM Microscopy unit, Assiut University, Egypt. Ten seeds were used in the morphological description. The terminology for seed characteristics follows Barthlott (1981), Anil Kumar et al. (2014).

Pollen preparations for SEM were done by mounting dry pollen grains directly onto clean stubs using double-side cello tape and silver best. Each sample was coated with gold in a Polaron E 5000. The pollens were examined by JEOL JSM scanning electron microscopy accelerated by a voltage of $15 \mathrm{kv}$ at SEM Microscopy unit, Assiut University, Egypt. The terminology for pollen characteristics follows Erdtman (1952) and Punt et al., (2007).

\section{Results and Discussion Description of seed characteristics}

Seed shape of the investigated species was obovate in S. abutiloides, S. coagulans, S. elaeagnifolium, $S$. laciniatum, $S$. lycopersicum, S. nigrum, S. seaforthianum, S. sinaicum, S. umbellatum, S. villosum and $S$. virginianum (Plate 1, Figs. 1,2); and reniform in the remaining taxa (Plate 1 , Fig. 3). Seeds dimension vary greatly among the examined taxa; their size ranged from $3.05 \pm 0.91$ in $S$. lycopersicum x 3.28 \pm 0.63 in S. diphyllum to $1.22 \pm 0.19 \times 1.14$ \pm 0.21 in $S$. abutiloides. The colour of the seeds in the studied species were yellow, reddish brown, dark brown and black. Seeds are black in $S$. coagulans, reddish brown in S. laciniatum, dark brown in S. forskalii, $S$. incanum, S. seaforthianum, S. sinaicum and $S$. virginianum and yellow in the remaining investigated taxa. Seed surface is of two main categories; smooth or hairy; they are hairy in $S$. nigrum, $S$. lycopersicum, S. seaforthianum and $S$. villosum but smooth in the remaining species. 
Table 1. List of Solanum species used in SEM studies on seed and pollen and their subgeneric and sectional delimitation and their source and/or site of collection

\begin{tabular}{|c|c|c|c|}
\hline Taxa & Subgenus & Section & Source and/or site \\
\hline $\begin{array}{l}\text { 1. Solanum abutiloides } \\
\text { (Griseb.) Bitter \& Lillo }\end{array}$ & Brevantherum & Brevantherum & $\begin{array}{l}\text { Zagazig: Botanic Garden, Faculty of } \\
\text { Pharmacy, Zagazig University, } \\
\text { 17.5.2017s.n.; Z. El-Sayed s.n, } \\
\text { (CAI) }\end{array}$ \\
\hline 2. S. diphyllum L. & Solanum & geminata & $\begin{array}{l}\text { Giza: Research institute of } \\
\text { vegetables and aromatic plants, } \\
\text { Dokki, 20.4.2017; M. Mahdy s.n. } \\
\text { (Helwan University herbarium) }\end{array}$ \\
\hline 3. S. laciniatum Aiton & Solanum & Archaeosolanum & $\begin{array}{l}\text { Faiyum, 30.9.1971; Imam et al. s.n. } \\
\text { (CAI) }\end{array}$ \\
\hline 4. S. nigrum L. & Solanum & Solanum & $\begin{array}{l}18 \text { km north of Senbellaein, Tal El- } \\
\text { Ruba, 21-24.7.1977; A. El-Gazzar } \\
\text { s.n. (CAI) }\end{array}$ \\
\hline 5. S. sinaicum Boiss. & Solanum & Solanum & $\begin{array}{l}\text { Sinai: outside St. Catherine } \\
\text { monastery, 23.4.1961; Vivi } \\
\text { Täckholm et al. s.n. (CAI) }\end{array}$ \\
\hline 6. S. umbellatum Mill. & Brevantherum & Brevantherum & $\begin{array}{l}\text { Giza: Baragile, 25.10.2016; Hamdy } \\
\text { s.n. (CAI) }\end{array}$ \\
\hline 7. S. villosum Mill. & Solanum & Solanum & $\begin{array}{l}\text { Giza: Faculty of Pharmacy Garden, } \\
\text { Boulaq El-Dakrour, 10.5.2015; M. } \\
\text { Mahdy s.n. (Helwan University } \\
\text { herbarium). }\end{array}$ \\
\hline 8. S. coagulans Forssk. & Leptostemonum & Monodolichopus & $\begin{array}{l}\text { Gebel Elba: Mersa Halaib, } \\
\text { 21.1.1929; Gunnar Täckholm s.n. } \\
\text { (CAI) }\end{array}$ \\
\hline 9. S. elaeagnifolium Cav. & Leptostemonum & Leprophora & $\begin{array}{l}\text { Shibin el Qanatir: 6.8.1974; Mahdi } \\
\text { Mohamed s.n. (CAI) }\end{array}$ \\
\hline 10. S. forskalii Dunal & Leptostemonum & Oliganthes & $\begin{array}{l}\text { Gebel Elba: upstream part of Wadi } \\
\text { Saremtai, 29.1.1962; Vivi Täckholm } \\
\text { s.n. (CAI); 23-27.1.1929; G, } \\
\text { Täckholm s.n. (CAI) }\end{array}$ \\
\hline 11. S. incanum L. & Leptostemonum & Melongena & $\begin{array}{l}\text { Gebel Elba: Khor across Gebel } \\
\text { Shallal, 24.1.1962; Vivi Täckholm } \\
\text { s.n. (CAI) }\end{array}$ \\
\hline 12. S. macrocarpon L. & Leptostemonum & Melongena & $\begin{array}{l}\text { Zagazig: Botanic Garden, Faculty of } \\
\text { Pharmacy, Zagazig University, } \\
\text { 17.5.2017; Z. El-Sayed s.n, (CAI) }\end{array}$ \\
\hline 13. S. melongena L. & Leptostemonum & Melongena & $\begin{array}{l}\text { Eastern Desert: St. Paul Monastery } \\
\text { Garden, 11.3.1954; L. Boulos s.n. } \\
\text { (CAI); N Qostul, 29.12.1963; L. } \\
\text { Boulos s.n. (CAI) }\end{array}$ \\
\hline 14. S. virginianum L. & Leptostemonum & Melongena & $\begin{array}{l}\text { Umm Gayli, Sennaar, 19.3.1938; } \\
\text { Vivi Täckholm } 691 \text { (CAI) }\end{array}$ \\
\hline $\begin{array}{l}\text { 15. S. schimperianum } \\
\text { Hochst ex Rich. }\end{array}$ & Leptostemonum & Giganteiformia & $\begin{array}{l}\text { Red Sea: Jebel Wad Nubao, } \\
\text { 23.12.1966; V. Täckholm } 997 \text { (CAI) }\end{array}$ \\
\hline 16. S. lycopersicum L. & Potatoe & Lycopersicum & $\begin{array}{l}\text { Helwan: gardens of Helwan } \\
\text { University, 14.1.2016; M. Mahdy } \\
\text { s.n. (Helwan University Herbarium) }\end{array}$ \\
\hline $\begin{array}{l}\text { 17. S. seaforthianum } \\
\text { Andrews }\end{array}$ & Potatoe & Jasminosolanum & $\begin{array}{l}\text { Giza: Orman garden, 12.4.1928; M. } \\
\text { Hassib s.n. (CAI) }\end{array}$ \\
\hline
\end{tabular}




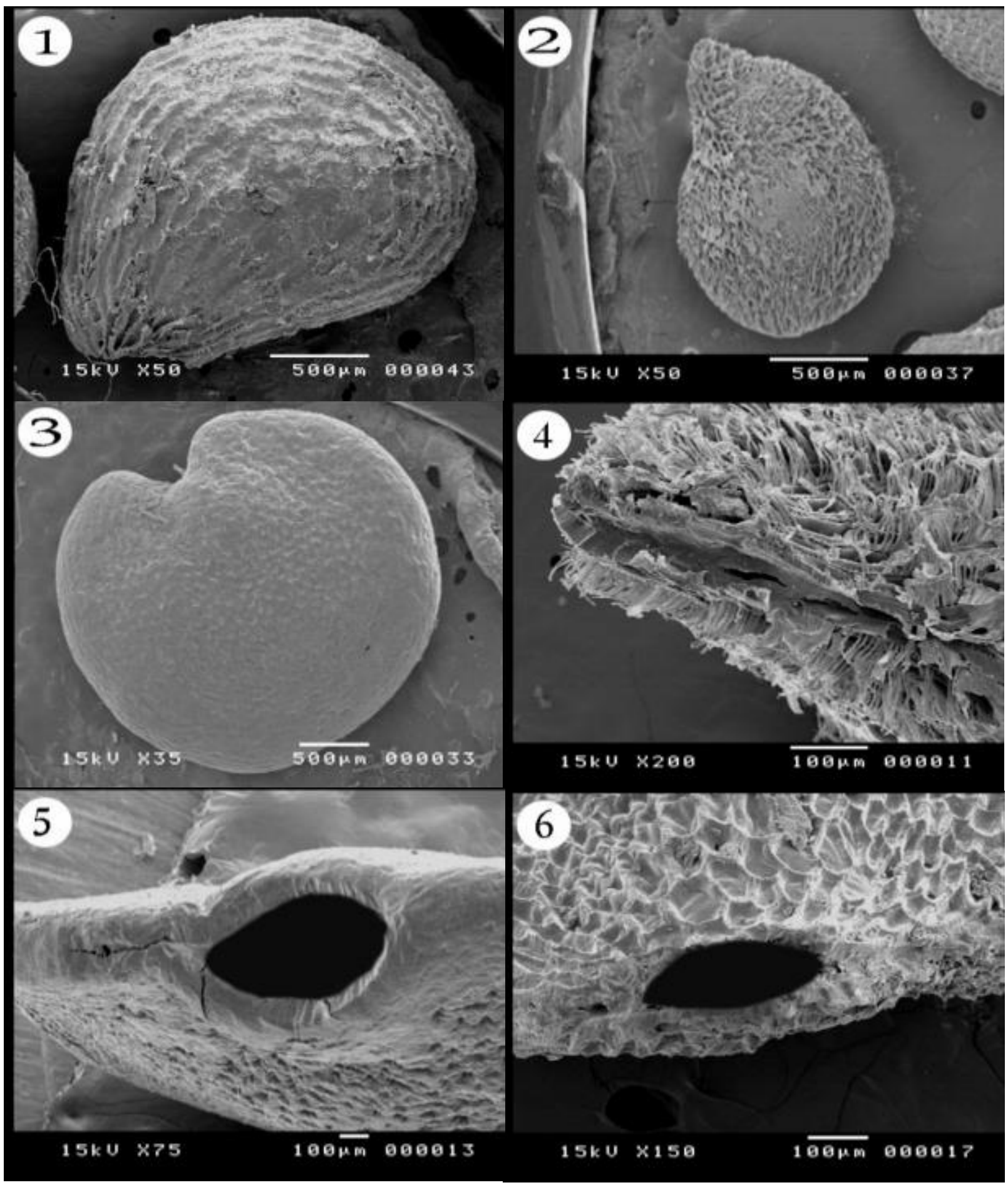

Plate I: Figs. 1-3. SEM micrographs of seed shape: Obovate Figs. 1-2 (S. abutiloides, S. coagulans, S. elaeagnifolium, S. incanum, S. laciniatum, S. lycopersicum, S. macrocarpon, S. nigrum, S. seaforthianum, S. sinaicum, S. umbellatum, S. villosum and S. virginianum): Fig.3 Reniform (S. diphyllum, S. forskalii, S. melongena and S. schimperianum; Figs. 4-6. SEM micrographs of hilum shape Fig.4. Slit like (S. diphyllum, S. nigrum and S. villosum), Fig.5. Rounded (S. abutiloides, S. laciniatum, S. schimperianum and S. umbellatum), Fig.6. Elliptical (S. coagulans, S. elaeagnifolium, S. forskalii, S. incanum, S. lycopersicum, S. macrocarpon, S. melongena, S. seaforthianum, S. sianicum and S. virginianum). 
Hilum shape varies from slit-like in $S$. villosum, S. diphyllum and S. nigrum (Plate 1, Fig. 4); round in S. abutiloides, S. umbellatum, S. laciniatum and S. schimperianum (Plate 1, Fig. 5); and elliptical in the remaining taxa (Plate 1, Fig. 6). Hilum dimension varies among the examined taxa; the largest hilum size (1.953 $\mathrm{mm} \times 0.578 \mathrm{~mm}$ ) was found in S. lycopersicum and the smallest hilum $(0.16 \mathrm{~mm} \times 0.065 \mathrm{~mm})$ in $S$. abutiloides. Hilum position is median in $S$. incanum, $S$. nigrum, $S$. sinaicum and $S$. virginianum; submedian-basal in $S$. abutiloides, $S$. laciniatum and S. lycopersicum but median in the remaining taxa. Hilum level varies from sunken in S. forskalii, S. laciniatum, $S$. lycopersicum, S. macrocarpon, S. melongena, $S$. seaforthianum and $S$. virginianum but slightly sunken in the remaining species.

Four different shapes of seed coat were recognized in the investigated taxa. It is cerebelloid in S. coagulans (Plate II, Fig. 2), $S$. incanum (Plate II, Fig. 6), S. macrocarpon (Plate II, Fig. 9), S. melongena (Plate II, Fig. 10), S. umbellatum (Plate II, Fig. 15) and $S$. virginianum (Plate II, Fig. 17); striated in $S$. laciniatum (Plate II, Fig. 7); without conspicuous cell in S. elaeagnifolium (Plate II, Fig. 4), S. lycopersicum (Plate II, Fig. 8), S. nigrum (Plate II, Fig. 11) and S. seaforthianum (Plate II, Fig. 13); and reticulate in the remaining taxa. Cell size varies from small, large, extremely large or not distinct between taxa. The cells are almost regular or irregular in shape; they are usually 4-7 gonal or 7-9 gonal. The cell pattern is not isodiametric in $S$. abutiloides (Plate II, Fig. 1), S. coagulans (Plate II, Fig. 2), S. diphyllum (Plate II, Fig. 3), S. forskalii (Plate II, Fig. 5), S. incanum (Plate II, Fig. 6), S. macrocarpon (Plate II, Fig. 9) and $S$. sinaicum (Plate II, Fig. 14); not isodiametric \& elongate in one direction in S. laciniatum(Plate 2, Fig. 7), S. nigrum (Plate II, Fig. 11) and $S$. villosum (Plate II, Fig. 16); nearly isodiametric in S. lycopersicum (Plate II, Fig. 8), $S$. macrocarpon (Plate II, Fig. 9), S. melongena (Plate III, Fig. 10), S. schimperianum (Plate II, Fig. 12), S. umbellatum (Plate II, Fig. 15) and $S$. virginianum (Plate II, Fig. 17); or conjugate in S. elaeagnifolium (Plate II, Fig. 4) and $S$. seaforthianum (Plate II, Fig. 13).

Three main categories of elevation of cell boundaries are recognized on the examined taxa. It is raised in S. nigrum (Plate II, Fig. 11), S. schimperianum (Plate II, Fig. 12), S. seaforthianum (Plate III, Fig. 13) and $S$. villosum (Plate II, Fig. 16) but slightly raised in the remaining taxa. The degree of sinuosity of cell boundaries varies from straight to sinous; it is sinous in S. coagulans (Plate II, Fig. 2), S. incanum (Plate II, Fig. 6), $S$. laciniatum (Plate II, Fig. 7), S. lycopersicum (Plate II, Fig. 8), S. macrocarpon (Plate II, Fig. 9), S. seaforthianum (Plate II, Fig. 13), S. villosum (Plate II, Fig. 16) and S. virginianum (Plate II, Fig. 17) and straight to - slightly sinous in the remaining species. Sculpture of cell boundaries showed great variation among taxa; it is smooth to - obscurely papillate in $S$. abutiloides (Plate II, Fig. 1); smooth in $S$. incanum (Plate II, Fig. 6); papillate in $S$. laciniatum (Plate II, Fig. 7) and $S$. schimperianum (Plate II, Fig. 12); pusticulated in S. sinaicum (Plate II, Fig. 14); striated in $S$. coagulans (Plate II, Fig. 2), S. elaeagnifolium (Plate II, Fig. 4)and S. umbellatum (Plate II, Fig. 15); but not distinct in the remaining species.

Distal appendages on the anticlinal wall may be present or absent If present, it may ribbon-like, fibrils. The ribbon-like is divided into six shapes: A- ribbon-like in S. abutiloides (Plate II, Fig. 1) and S. forskalii (Plate II, Fig. 5); B- very thin ribbon-like deeply divided forming loops in S. melongena (Plate 3, Fig. 10 ); C- thin ribbon-like forming loops in $S$. incanum (Plate II, Fig. 6) and S. virginianum (Plate II, Fig. 17); D- thick ribbon-like forming loops in S. macrocarpon (Plate II, Fig. 9); Ethin ribbon-like in a depression in $S$. umbellatum (Plate II, Fig. 15); F- minute ribbon-like, flap-like with finger like laciniations in S. diphyllum (Plate II, Fig. 3). The fibril is of two main types either radiate in S. lycopersicum (Plate II, Fig. 8) or palaceous in $S$. nigrum (Plate II, Fig. 11), $S$. seaforthianum (Plate II, Fig. 13) and $S$. villosum (Plate II, Fig. 16).

Two types of periclinal cell wall elevation were recorded, the outer periclinal cell wall is concave in S. forskalii (Plate II, Fig. 5), S. nigrum (Plate II, Fig. 11), S. villosum (Plate II, Fig. 16), S. virginianum (Plate II, Fig. 17) and S. umbellatum (Plate II, Fig. 15) or flat to slightly concave in the remaining taxa. The 

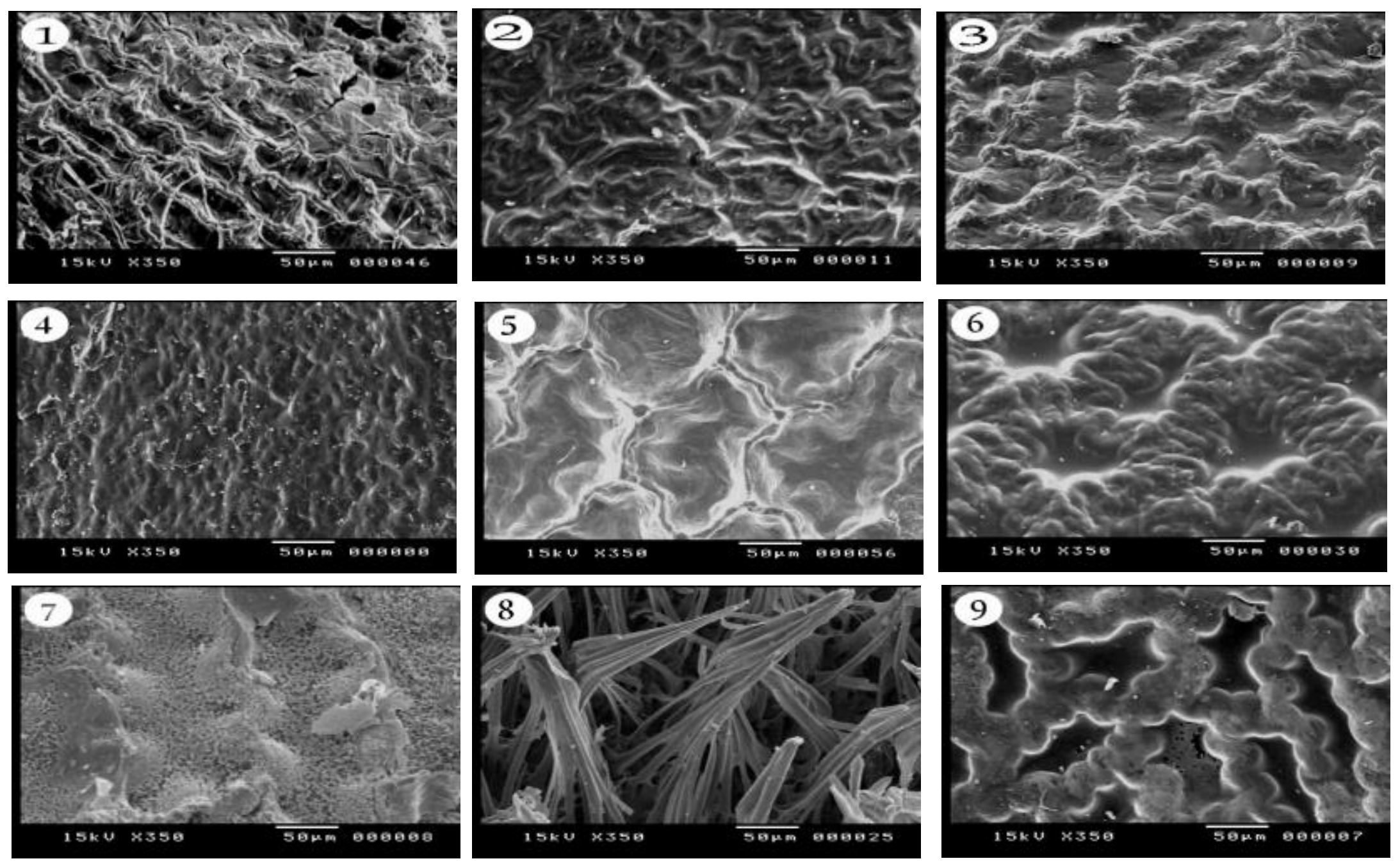

Plate II: SEM micrographs of seed coat morphology: Fig.1. S. abutiloides, Fig.2. S. coagulans, Fig.3. S. diphyllum, Fig.4. S. elaeagnifloium, Fig.5. S. forskalii, Fig.6. S. incanum, Fig.7. S. laciniatum, Fig.8. S. lycopersicum; Fig.9. S. macrocarpon. 

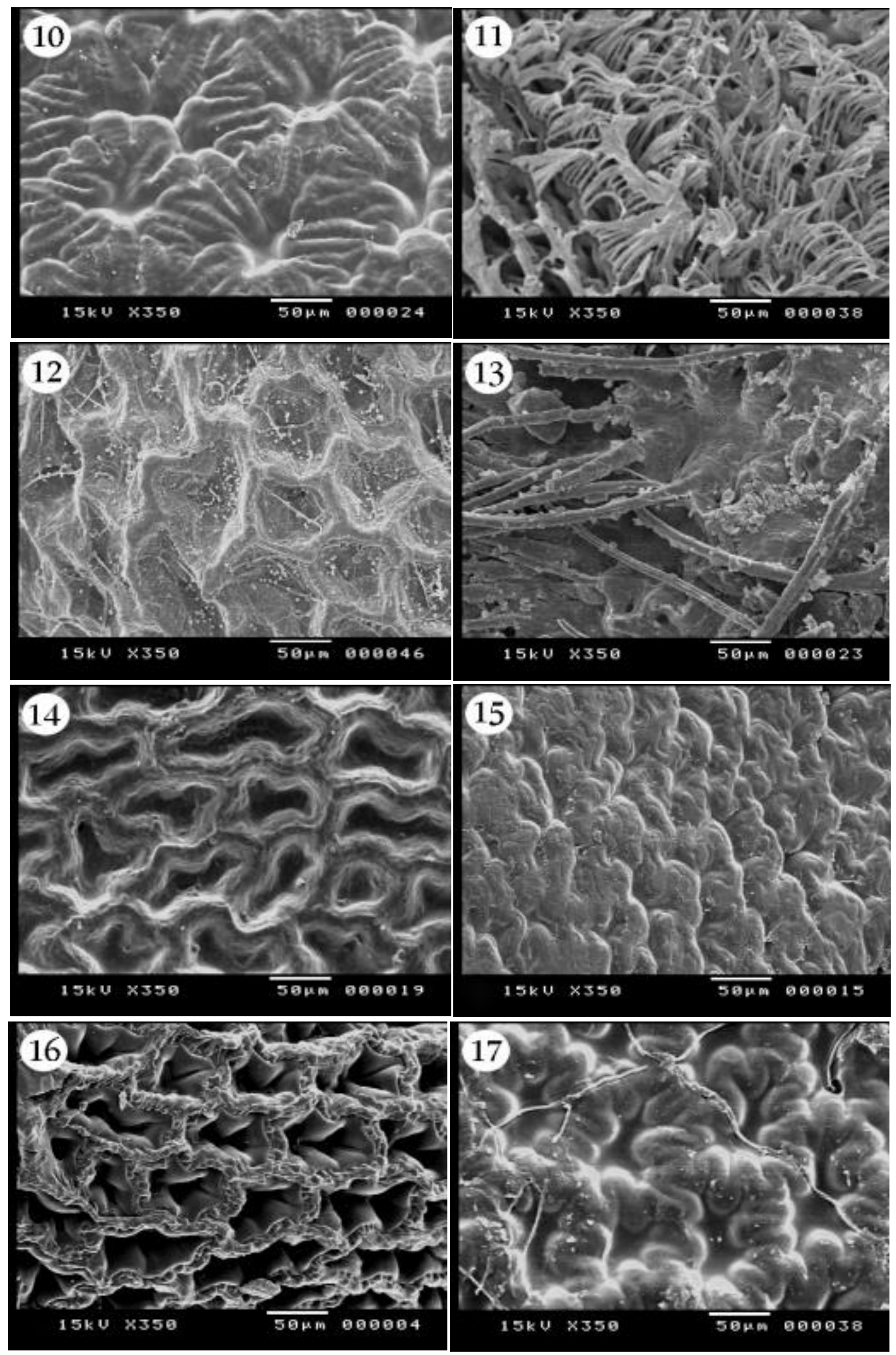

Plate II (cont.): SEM micrographs of seed coat morphology, Fig.10. S. melongena, Fig.11. S. nigrum, Fig.12. S. schimperianum, Fig.13. S. seaforthianum, Fig.14. S. sinaicum, Fig.15. S. umbellatum, Fig.16. S. villosum, Fig.17. S. virginianum. 


\section{Description of seed and pollen micromorphology}

sculpture of periclinal cell wall showed great variation among the investigated species. It ranges from smooth in $S$. melongena (Plate II, Fig. 10); smooth-papillate in S. macrocarpon (Plate II, Fig. 9); papillate in S. forskalii (Plate II, Fig. 5), S. lycopersicum (Plate II, Fig. 8), S. nigrum (Plate III, Fig. 11), S. schimperianum
(Plate II, Fig. 12), S. sinaicum (Plate II, Fig. 14); smooth- verrucate in $S$. abutiloides (Plate II, Fig. 1); reticulate- foveate in S. laciniatum (Plate II, Fig. 7); perforate-microreticulate in S. seaforthianum (Plate II, Fig. 13); but not prominent due to inconspicuous cell lumen in the remaining species.

\section{Identification Key based on seed features}

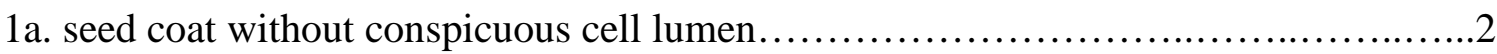

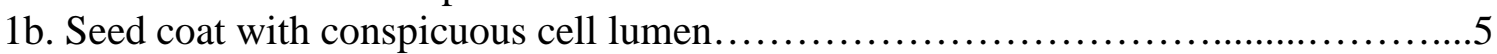

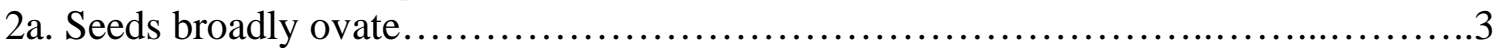

2b. Seeds obovate-reniform.......................................................

3a. Anticlinal wall sinuate.......................................... seaforthianum

3b. Anticlinal wall straight- slightly sinuate............................ elaeagnifolium

4a. Epidermal cells irregular, 5-7-gonal; elongate in one direction.............. S. nigrum

4b. Epidermal cells nearly isodiametric.............................. S. lycopersicum

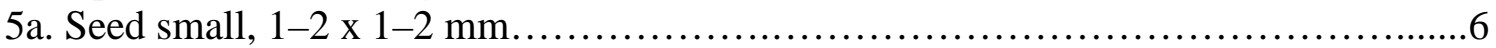

5b. Seed large, $2.4-4$ x 1-3 mm............................................................

6a. Seed coat cerebelloid ............................................. virginianum

6b. Seed coat reticulate............................................................. 7

7a. Periclinal wall verrucate............................................. abutiloides

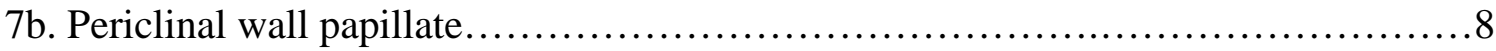

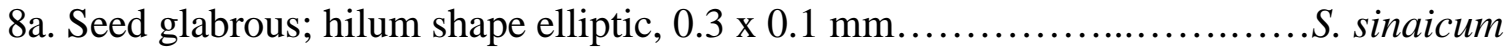

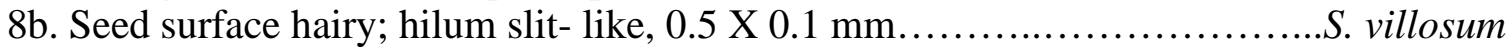

9a. Seed coat striate, disconnected longitudinal furrowed.................... S. laciniatum

9b. Seed coat cerebelloid or reticulate............................................ 10

10a. Seed coat reticulate...........................................................

10b. Seed coat cerebelloid ....................................................... 13

11a. Hilum \pm rounded, 0.3 x $0.2 \mathrm{~mm} \ldots \ldots \ldots \ldots \ldots \ldots \ldots \ldots \ldots \ldots \ldots \ldots \ldots \ldots \ldots \ldots$. schimperianum

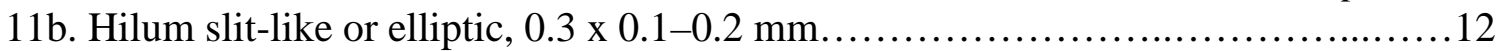

12a. Hilum slit-like, anticlinal wall straight- slightly sinuate.................. S. diphyllum

12b. Hilum elliptic, anticlinal wall slightly sinuate........................... S. forskalii

13a. Epidermal cells 5-7-gonal....................................................... 14

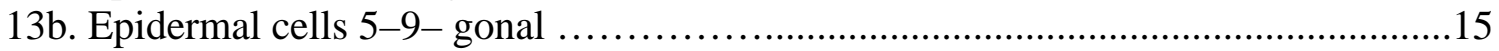

14a. Seeds $2-3$ x 2-3 mm; epidermal cells irregular..................................... incanum

14b. Seeds 3-3.5 x 2-3 mm; epidermal cells regular............................. umbellatum

15a. Periclinal wall striate; seeds black.................................. S. coagulans

15b. Periclinal wall smooth; seeds yellowish or pale brown............................16

16a. Anticlinal wall sinuate, hilum elliptic................................ S. macrocarpon

16b. Anticlinal wall straight - slightly sinuate, hilum rounded................. melongena

\section{Description of pollen characteristics}

Pollen grain size in polar view ranges from $15 \pm 0.50 \mu$ in S. seaforthianum to $34 \pm 2$ $\mu \mathrm{m}$ in $S$. laciniatum but in the equatorial view it ranges from $9.06 \pm 1.94 \mu \mathrm{m}$ in S. diphyllum to $25 \pm 2 \mu \mathrm{m}$ in $S$. macrocarpon. Four different shapes of pollen were recognized in the polar view; trilobed in $S$. nigrum and $S$. seaforthianum; elliptical in S. laciniatum, $S$. lycopersicum, S. sinaicum and S. villosum; circular in S. forskalii, S. macrocarpon and S. melongena; and triangular in the remaining taxa. There are also four different shapes of pollen in the equatorial view; broad elliptic in $S$. elaeagnifolium; rhombic-elliptic in $S$. schimperianum; circular in $S$. forskalii, $S$. incanum and $S$. macrocarpon; and elliptic in the remaining taxa. 
Six distinct types of pollen shapes were differentiated; oblate-spheroidal in $S$. seaforthianum (Plate III, Figs. 9,10); spherical in S. incanum (Plate III, Figs. 5,6); subprolate in S. elaeagnifolium, S. forskalii, S. melongena and S. schimperianum (Plate III, Figs. 3,4); perprolate in $S$. lycopersicum and S. sinaicum (Plate III, Figs. 11,12); prolate-spheroidal in $S$. macrocarpon (Plate III, Figs. 7,8); and prolate in the remaining species (Plate III, Figs. 1,2). The pollen grains have tricolporate aperture in all studied species.

The aperture type in all the investigated species are tricolporate, with very small bridged pores. Colpus size ranges from 13.8 $\mu \mathrm{m}$ in S. diphyllum to $30 \mu \mathrm{m}$ in S. laciniatum. Colpus apex may be obtuse in $S$. elaeagnifolium, S. forskalii, S. incanum, S. melongena, $S$. nigrum and $S$. schimperianum or acute in the remaining taxa. The colpi are syncolpate in $S$. abutiloides, S. coagulans, $S$. eleaegnifolium, S. forskalii, S. incanum, S. macrocarpon, $S$. melongena, $S$. schimperianum and $S$. seaforthianum, while they are apocolpate in the rest of the species. There are four different exine ornamentation in the investigated taxa; verrucate in $S$. coagulans (Plate IV, Fig. 1); scabrate in S. abutiloides, $S$. incanum and S. nigrum (Plate IV, Fig. 2); granulate in $S$. laciniatum, $S$. macrocarpon, $S$. melongena, S. schimperianum and S. villosum (Plate IV, Fig. 3); and psilate in the remaining taxa (Plate IV, Fig. 4).

\section{Taxonomic impact of seed and pollen characteristics}

Seed and pollen morphological and microscopic characters were helpful in distinguishing the majority of the examined species (Table $2 \& 3$ ). These characters were also useful in preparing an identification key for the studied species of Solanum. However, the pollen and seed traits do not confirm the sectional classification of some species of the studied taxa as proposed by Lester et al. (2011) as for $S$. diphyllum, $S$. coagulans, $S$. elaeagifolium, $S$. lycopersicum and $S$. seaforthianum. The identification key divided the species into two groups based on the seed shape. The $S$. lycopersicum and $S$. seaforthianum which are delimited in subgenus Potatoe due to their morphological characters but based on seed characters they are similar to the species of subgenus Solanum because the seed surface is hairy. Solanum diphyllum belongs to subgenus Solanum but in resemblance with the species of subgenus Leptostemonum due to its seed shape is reinform and presence of appendages on anticlinal cell wall which is minute ribbon flap like with finger like projection. Seed colour was found useful to distinguish $S$. coagulans from the other species which have seed colour black.

Junlakitjawat et al., (2010) noted the presence of fibrils or hairs on $S$. nigrum seeds of the paleaceous type growing out from the muri and on S. lycopersicum with thicker base and finely tapering tips; this observation agrees with our results. On the other hand, Lashin (2011) observed that the pollen shape of $S$. nigrum and $S$. villosum was prolate-spheroidal but our observation indicated that the pollen shape in these two species is prolate. He regarded pollen shape of $S$. incanum is prolate which is spherical in the examined material we examined of this species. Pollen shape for $S$. incanum, S. nigrum and S. villosum agree with the differences in morphology and seed characters.

The observed differences in pollen morphology between the studied species agree with the observations of Gbile \& Sowunmi (1979) that conducted a palynological study in Solanum species and found highly significant differences in pollen size and shape within the studied groups (Bonnefille \& Riollet; 1980 \& El-Ghazali,1993). Perveen and Qaiser (2007) reported that pollen shape of $S$. seaforthianum was prolate which is inconsistent with our result indicating that it is oblate-spheroidal but agree with them in S. nigrum ornamentation which scabrate. Anil Kumar et al. (2015) described pollen shape for $S$. seaforthianum as spherical which conflicts with our records of oblate-spheroidal and also for S. melongena that was regarded as prolate-spheroidal but in our material, it is subprolate. However, our results agree with the above authors for pollen shape of $S$. macrocarpon which was prolatespheroidal. 


\section{Description of seed and pollen micromorphology}

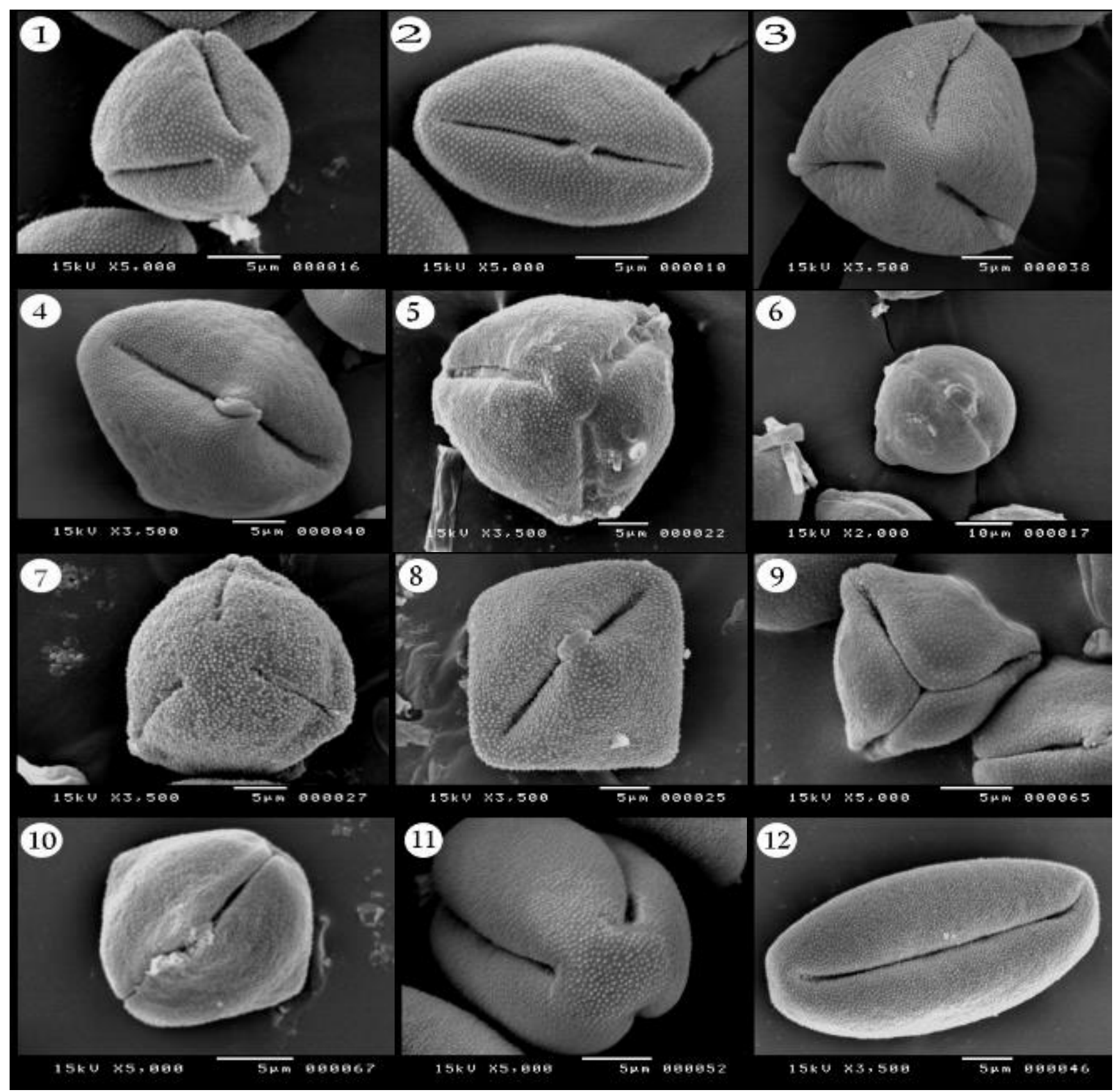

Plate III: SEM micrographs of pollen shapes common in the examined Solanum species. Fig.1. Prolate- Polar view, Fig.2. Prolate- Equatorial view (S. abutiloides, S. coagulans, S. diphyllum, S. laciniatum, S. nigrum, S. umbellatum and S. villosum), Fig.3. Sub-prolate- Polar view, Fig.4.Subprolate- Equatorial view (S. elaeagnifolium, S. forskalii, S. melongena and S. schimperianum), Fig.5. Spherical- Polar view, Fig.6. Spherical- Equatorial view (S. incanum), Fig.7. Prolatespheroidal- Polar view, Fig.8. Prolate-spheroidal- Equatorial view (S. macrocarpon), Fig.9. Oblate-spheroidal- Polar view, Fig.10. Oblate-spheroidal- Equatorial view (S. seaforthianum), Fig.11. Perprolate- Polar view, Fig.12. Perprolate- Equatorial view (S. lycopersicum and S. sinaicum). 


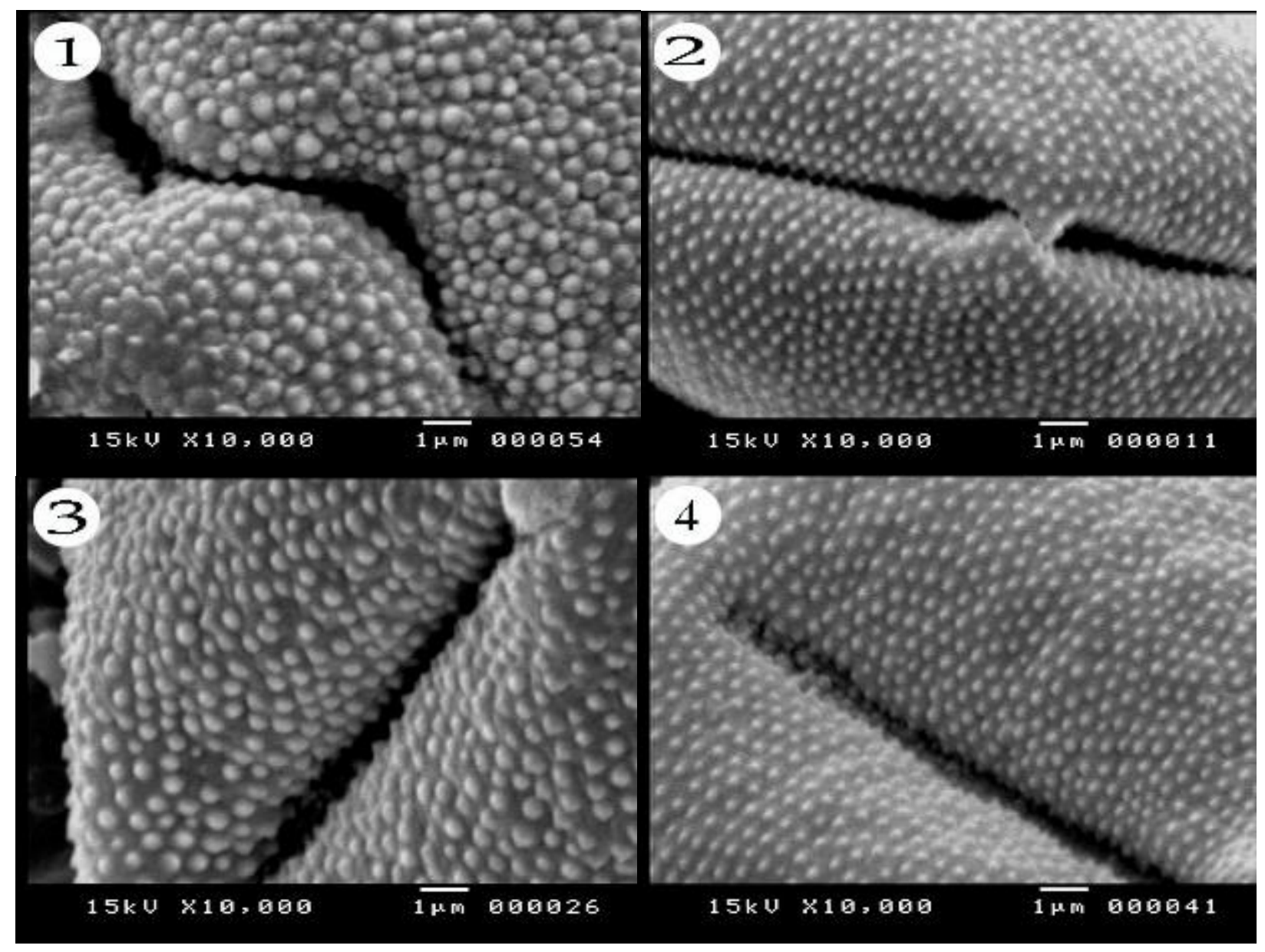

Plate IV: SEM micrographs of pollen sculpture common in the examined Solanum species. Fig.1. Verrucate (S. coagulans), Fig.2. Scabrate (S. abutiloides, S. incanumand S. nigrum), Fig.3. Granulate (S. laciniatum, S. macrocarpon, S. melongena, S. schimperianumand $S$. villosum), Fig.4. Psilate (S. diphyllum, S. elaeagnifolium, S. forskalii, S. lycopersicum, S. seaforthianum, S. sinaicumand S. umbellatum). 


\section{Description of seed and pollen micromorphology}

Table 2. Seed shape, size and seed coat and hilum characteristics in the studied Solanum taxa

\begin{tabular}{|c|c|c|c|c|c|c|c|c|c|c|}
\hline \multirow[t]{2}{*}{ Taxa } & \multirow{2}{*}{$\begin{array}{l}\text { Seed } \\
\text { shape }\end{array}$} & \multirow{2}{*}{$\begin{array}{c}\text { Seed size } \\
\text { LxW (mm) }\end{array}$} & \multirow{2}{*}{$\begin{array}{l}\text { Seed } \\
\text { colour }\end{array}$} & \multicolumn{2}{|c|}{ Hilum scar } & \multirow{2}{*}{$\begin{array}{c}\text { Seed coat } \\
\text { appearance }\end{array}$} & \multirow{2}{*}{$\begin{array}{l}\text { Epidermal cell } \\
\text { shape }\end{array}$} & \multicolumn{2}{|c|}{ Anticlinal wall } & \multirow{2}{*}{$\begin{array}{l}\text { Periclinal cell } \\
\text { wall }\end{array}$} \\
\hline & & & & Shape & $\begin{array}{l}\text { LxW } \\
(\mathbf{m m})\end{array}$ & & & $\begin{array}{c}\text { Cell } \\
\text { boundaries }\end{array}$ & $\begin{array}{c}\text { Distal } \\
\text { appendages }\end{array}$ & \\
\hline 1. S. abutiloides & obovate & $\begin{array}{l}1.22 \pm 0.19 \\
\text { x } 1.14 \pm \\
0.21\end{array}$ & $\begin{array}{l}\text { yellowish- } \\
\text { pale brown }\end{array}$ & rounded & $\begin{array}{l}0.2 \times \\
0.1\end{array}$ & reticulate & $\begin{array}{l}\text { irregular, 6-7 } \\
\text { gonal; small }\end{array}$ & $\begin{array}{l}\text { straight- } \\
\text { slightly sinous; } \\
\text { smooth- } \\
\text { papillate }\end{array}$ & $\begin{array}{l}\text { ribbon- like with } \\
\text { papillate surface }\end{array}$ & $\begin{array}{l}\text { slightly concave; } \\
\text { smooth- verrucate }\end{array}$ \\
\hline 2. S. coagulans & $\begin{array}{l}\text { obovate- } \\
\pm \\
\text { reniform } \\
\end{array}$ & $\begin{array}{l}3 \pm 0.24 x \\
3.14 \pm 0.33\end{array}$ & $\begin{array}{l}\text { dark } \\
\text { brown- } \\
\text { black } \\
\end{array}$ & elliptical & $\begin{array}{l}0.3 \mathrm{x} \\
0.2\end{array}$ & cerebelloid & $\begin{array}{l}\text { irregular, 7-9 } \\
\text { gonal; extremely } \\
\text { large }\end{array}$ & sinous; striated & absent & $\begin{array}{l}\text { slightly concave; } \\
\text { striated }\end{array}$ \\
\hline 3. S. diphyllum & reniform & $\begin{array}{l}2.94 \pm 0.52 \\
\text { x } 3.28 \pm \\
0.63\end{array}$ & $\begin{array}{l}\text { yellowish- } \\
\text { pale brown }\end{array}$ & slit-like & $\begin{array}{l}0.3 \mathrm{x} \\
0.1\end{array}$ & reticulate & $\begin{array}{l}\text { irregular, } 4 \text {-7 } \\
\text { gonal; small }\end{array}$ & $\begin{array}{l}\text { straight- } \\
\text { slightly sinous }\end{array}$ & $\begin{array}{l}\text { minute ribbon, } \\
\text { flap-like with } \\
\text { finger- like } \\
\text { projections }\end{array}$ & $\begin{array}{l}\text { flat- slightly } \\
\text { concave and } \\
\text { finely striated }\end{array}$ \\
\hline $\begin{array}{l}\text { 4. S. } \\
\text { elaeagnifolium }\end{array}$ & $\begin{array}{l}\text { broadly } \\
\text { ovate- } \pm \\
\text { reniform }\end{array}$ & $\begin{array}{l}2.54 \pm 0.41 \\
\text { x } 2.54 \pm \\
0.37\end{array}$ & $\begin{array}{l}\text { yellowish- } \\
\text { pale brown }\end{array}$ & elliptical & $\begin{array}{l}0.6 \mathrm{x} \\
0.3\end{array}$ & $\begin{array}{l}\text { without } \\
\text { conspicuous } \\
\text { cell lumen }\end{array}$ & $\begin{array}{l}\text { irregular; } \\
\text { conjugate }\end{array}$ & $\begin{array}{l}\text { straight- lightly } \\
\text { sinous; striated }\end{array}$ & absent & slightly concave; \\
\hline 5. S. forskalii & reniform & $\begin{array}{l}2.9 \pm 0.64 \\
\times 3.08 \pm \\
1.05\end{array}$ & $\begin{array}{l}\text { dark } \\
\text { brown }\end{array}$ & elliptical & $\begin{array}{l}0.3 \mathrm{x} \\
0.2\end{array}$ & reticulate & $\begin{array}{l}\text { irregular, 5-7 } \\
\text { gonal; large }\end{array}$ & slightly sinous & ribbon- like & $\begin{array}{l}\text { concave; papillate } \\
\text { on the foveate } \\
\text { surface }\end{array}$ \\
\hline 6. S. incanum & $\begin{array}{l}\text { obovate- } \\
\pm \\
\text { reniform }\end{array}$ & $\begin{array}{l}2.61 \pm 0.42 \\
\text { x } 2.48 \pm \\
0.32\end{array}$ & $\begin{array}{l}\text { yellowish- } \\
\text { brown }\end{array}$ & elliptical & $\begin{array}{l}0.2 \mathrm{x} \\
0.1\end{array}$ & cerebelloid & $\begin{array}{l}\text { regular, 5-7 } \\
\text { gonal; large }\end{array}$ & sinous; smooth & $\begin{array}{l}\text { thin ribbon } \\
\text { forming } \\
\text { irregular loops }\end{array}$ & slightly concave \\
\hline 7. S. Iaciniatum & obovate & $\begin{array}{l}2.31 \pm 0.19 \\
\text { x } 1.87 \pm \\
0.18\end{array}$ & pale brown & rounded & $\begin{array}{l}0.5 \mathrm{x} \\
0.2\end{array}$ & $\begin{array}{l}\text { striate, } \\
\text { disconnected } \\
\text { longitudinal } \\
\text { furrowed }\end{array}$ & $\begin{array}{l}\text { regular, } 4 \text { gonal; } \\
\text { elongate in one } \\
\text { direction; } \\
\text { extremely large }\end{array}$ & $\begin{array}{l}\text { sinous; } \\
\text { papillate }\end{array}$ & absent & $\begin{array}{l}\text { slightly concave, } \\
\text { reticulate- } \\
\text { foveate, papillate }\end{array}$ \\
\hline 8. S. lycopersicum & obovate & $\begin{array}{l}3.05 \pm 0.91 \\
\times 2.32 \pm \\
0.73 \\
\end{array}$ & $\begin{array}{l}\text { yellowish- } \\
\text { brown }\end{array}$ & elliptical & $\begin{array}{l}2 x \\
0.6\end{array}$ & $\begin{array}{l}\text { without } \\
\text { conspicuous } \\
\text { cell lumen } \\
\end{array}$ & $\begin{array}{l}\text { 4-7 gonal; small } \\
\text { nearly } \\
\text { isodiametric; }\end{array}$ & sinous & $\begin{array}{l}\text { fibrils radiate } \\
\text { type with saw- } \\
\text { like margin }\end{array}$ & $\begin{array}{l}\text { slightly concave, } \\
\text { papillate }\end{array}$ \\
\hline 9. S. macrocarpon & $\begin{array}{l}\text { obovate- } \\
\pm \\
\text { reniform }\end{array}$ & $\begin{array}{l}2.75 \pm 0.25 \\
\text { x } 2.75 \pm \\
0.25\end{array}$ & $\begin{array}{l}\text { Pale } \\
\text { brown }\end{array}$ & elliptical & $\begin{array}{l}0.4 \mathrm{x} \\
0.2\end{array}$ & cerebelloid & $\begin{array}{l}\text { 7-9 gonal; nearly } \\
\text { isodiametric; } \\
\text { large }\end{array}$ & sinous & $\begin{array}{l}\text { thick ribbon-like } \\
\text { forming } \\
\text { irregular loops }\end{array}$ & $\begin{array}{l}\text { slightly concave, } \\
\text { smooth- } \\
\text { obscurely } \\
\text { papillate }\end{array}$ \\
\hline
\end{tabular}




\section{Mayada Mahdy et al.}

\begin{tabular}{|c|c|c|c|c|c|c|c|c|c|c|}
\hline 10. S. melongena & reniform & $\begin{array}{l}2.92 \pm 0.34 \\
\text { x } 2.94 \pm \\
0.44\end{array}$ & $\begin{array}{l}\text { yellowish } \\
\text {-pale } \\
\text { brown }\end{array}$ & elliptical & $\begin{array}{l}0.8 \mathrm{x} \\
0.3\end{array}$ & cerebelloid & $\begin{array}{l}\text { regular, 7-9 } \\
\text { gonal; nearly } \\
\text { isodiametric; } \\
\text { small }\end{array}$ & $\begin{array}{l}\text { straight- } \\
\text { slightly sinous }\end{array}$ & $\begin{array}{l}\text { very thin ribbon- } \\
\text { like deeply } \\
\text { divided }\end{array}$ & $\begin{array}{l}\text { slightly concave, } \\
\text { smooth }\end{array}$ \\
\hline 11. S. nigrum & obovate & $\begin{array}{l}1.84 \pm 0.38 \\
\text { x } 1.58 \pm \\
0.23\end{array}$ & $\begin{array}{l}\text { pale } \\
\text { yellowish- } \\
\text { pale brown }\end{array}$ & slit-like & $\begin{array}{l}0.6 \mathrm{x} \\
0.1\end{array}$ & $\begin{array}{l}\text { without } \\
\text { conspicuous } \\
\text { cell lumen }\end{array}$ & $\begin{array}{l}\text { irregular, 5-7 } \\
\text { gonal; elongate } \\
\text { in one direction; } \\
\text { small }\end{array}$ & slightly sinous & $\begin{array}{l}\text { short fibrils } \\
\text { palaceous type, } \\
\text { with pyramid- } \\
\text { shaped base }\end{array}$ & concave, papillate \\
\hline $\begin{array}{l}\text { 12. } S . \\
\text { schimperianum }\end{array}$ & reniform & $\begin{array}{l}2.42 \pm 0.43 \\
\text { x } 2.52 \pm \\
0.41\end{array}$ & $\begin{array}{l}\text { pale } \\
\text { yellow- } \\
\text { brown }\end{array}$ & rounded & $\begin{array}{l}0.3 \mathrm{x} \\
0.2\end{array}$ & reticulate & $\begin{array}{l}\text { polygonal 5-7 } \\
\text { gonal; large } \\
\text { nearly } \\
\text { isodiametric; }\end{array}$ & $\begin{array}{l}\text { straight- } \\
\text { slightly sinous; } \\
\text { papillate }\end{array}$ & absent & $\begin{array}{l}\text { slightly concave, } \\
\text { papillate }\end{array}$ \\
\hline $\begin{array}{l}\text { 13. S. } \\
\text { seaforthianum }\end{array}$ & $\begin{array}{l}\text { broadly } \\
\text { ovate- } \pm \\
\text { reniform }\end{array}$ & $\begin{array}{l}2.75 \pm 0.25 \\
\times 2.75 \pm \\
0.25\end{array}$ & $\begin{array}{l}\text { pale } \\
\text { yellowish- } \\
\text { reddish } \\
\text { brown }\end{array}$ & elliptical & $\begin{array}{l}0.3 \mathrm{x} \\
0.1\end{array}$ & $\begin{array}{l}\text { without } \\
\text { conspicuous } \\
\text { cell lumen due } \\
\text { to profuse } \\
\text { surface hairs } \\
\end{array}$ & $\begin{array}{l}\text { irregular, 7-9 } \\
\text { gonal; conjugate; } \\
\text { large }\end{array}$ & sinous & $\begin{array}{l}\text { fibrils palaceous } \\
\text { type, verrucate } \\
\text { with thickened } \\
\text { base }\end{array}$ & $\begin{array}{l}\text { slightly concave, } \\
\text { perforate- } \\
\text { microreticulate }\end{array}$ \\
\hline 14. S. sinaicum & Obovate & $\begin{array}{l}1.88 \pm 0.17 \\
\text { x } 1.61 \pm \\
0.24\end{array}$ & $\begin{array}{l}\text { yellow- } \\
\text { brown }\end{array}$ & elliptical & $\begin{array}{l}0.3 \mathrm{x} \\
0.1\end{array}$ & reticulate & $\begin{array}{l}\text { irregular, 5-7 } \\
\text { gonal; small }\end{array}$ & $\begin{array}{l}\text { straight- } \\
\text { slightly sinous; } \\
\text { densely } \\
\text { pusticulate }\end{array}$ & absent & $\begin{array}{l}\text { slightly concave, } \\
\text { papillate }\end{array}$ \\
\hline 15. S. umbellatum & $\begin{array}{l}\text { broadly } \\
\text { ovate- } \pm \\
\text { reniform }\end{array}$ & $\begin{array}{l}3 \pm 0.24 x \\
2.92 \pm 0.45\end{array}$ & yellow & rounded & $\begin{array}{l}0.6 \mathrm{x} \\
0.3\end{array}$ & cerebelloid & $\begin{array}{l}\text { irregular, 5-7 } \\
\text { gonal; nearly } \\
\text { isodiametric; } \\
\text { small }\end{array}$ & $\begin{array}{l}\text { slightly sinous; } \\
\text { striated }\end{array}$ & $\begin{array}{l}\text { thin minute } \\
\text { ribbon in a } \\
\text { depression }\end{array}$ & $\begin{array}{l}\text { concave, not } \\
\text { prominent due to } \\
\text { inconspicuous } \\
\text { lumen }\end{array}$ \\
\hline 16. S. villosum & $\begin{array}{l}\text { obovate- } \\
\pm \\
\text { reniform } \\
\text { rounded }\end{array}$ & $\begin{array}{l}1.58 \pm 0.36 \\
\text { x } 1.25 \pm \\
0.16\end{array}$ & $\begin{array}{l}\text { pale } \\
\text { yellow- } \\
\text { brown }\end{array}$ & slit-like & $\begin{array}{l}0.5 \mathrm{x} \\
0.1\end{array}$ & reticulate & $\begin{array}{l}\text { irregular, 5-7 } \\
\text { gonal; elongate } \\
\text { in one direction; } \\
\text { large }\end{array}$ & sinous & $\begin{array}{l}\text { short fibrils } \\
\text { palaceous type, } \\
\text { with pyramid- } \\
\text { shaped base \& } \\
\text { articulated } \\
\text { surface }\end{array}$ & concave, papillate \\
\hline 17. S. virginianum & Obovate & $\begin{array}{l}1.9 \pm 0.1 \mathrm{x} \\
2.4 \pm 0.1\end{array}$ & brown & elliptical & $\begin{array}{l}0.4 \mathrm{x} \\
0.2\end{array}$ & cerebelloid & $\begin{array}{l}\text { irregular, 7-9 } \\
\text { gonal; nearly } \\
\text { isodiametric; } \\
\text { large }\end{array}$ & sinous & $\begin{array}{l}\text { ribbon- like thin } \\
\text { forming loops on } \\
\text { top of muri }\end{array}$ & concave \\
\hline
\end{tabular}




\section{Description of seed and pollen micromorphology}

Table 3. Pollen characteristics in the studied Solanum taxa

\begin{tabular}{|c|c|c|c|c|c|c|c|c|c|c|c|}
\hline Taxa & PA $(\mu \mathrm{m})$ & $\mathrm{EA}(\mu \mathrm{m})$ & $\mathbf{P} / \mathbf{E}$ & Amb & Shape & $\begin{array}{c}\text { Aperture } \\
\text { type }\end{array}$ & $\begin{array}{l}\text { Pore size } \\
\text { LxW ( } \mu \mathrm{m})\end{array}$ & Colpus & $\begin{array}{c}\text { Colpus } \\
\text { length } \\
(\mu \mathrm{m})\end{array}$ & $\begin{array}{l}\text { Colpus } \\
\text { apex }\end{array}$ & $\begin{array}{c}\text { Exine } \\
\text { ornamentation }\end{array}$ \\
\hline 1. S. abutiloides & $\begin{array}{l}20.63 \pm \\
1.37\end{array}$ & $\begin{array}{l}12.03 \pm \\
1.97\end{array}$ & 1.71 & Triangular & Prolate & Tricolporate & $2.34 \times 2.19$ & Syncolpate & 17.19 & Acute & Scabrate \\
\hline 2. S. coagulans & $\begin{array}{l}31.52 \pm \\
2.48\end{array}$ & $20 \pm 2$ & 1.58 & Triangular & Prolate & Tricolporate & $4.35 \times 3.91$ & Syncolpate & 27.69 & Acute & Verrucate \\
\hline 3. S. diphyllum & $\begin{array}{l}15.94 \pm \\
0.09\end{array}$ & $\begin{array}{l}9.06 \pm \\
1.94\end{array}$ & 1.76 & Triangular & Prolate & Tricolporate & $2.34 \times 1.56$ & Apocolpate & 13.75 & Acute & Psilate \\
\hline $\begin{array}{l}\text { 4. S. } \\
\text { elaeagnifolium }\end{array}$ & $\begin{array}{l}27.83 \pm \\
2.63\end{array}$ & $\begin{array}{l}21.74 \pm \\
2.68\end{array}$ & 1.28 & Triangular & Sub-prolate & Tricolporate & $5.43 \times 6.52$ & Syncolpate & 23.26 & Obtuse & Psilate \\
\hline 5. S. forskalii & $\begin{array}{l}22.39 \pm \\
2.36\end{array}$ & $\begin{array}{l}19.35 \pm \\
1.65\end{array}$ & 1.16 & Circular & Sub-prolate & Tricolporate & $4.35 \times 4.35$ & Syncolpate & 20.65 & Obtuse & Psilate \\
\hline 6. S. incanum & $\begin{array}{l}23.85 \pm \\
1.45\end{array}$ & $\begin{array}{l}23.85 \pm \\
1.65\end{array}$ & 1 & Triangular & Spherical & Tricolporate & $4.0 \times 4.8$ & Syncolpate & 22.69 & Obtuse & Scabrate \\
\hline 7. S. Iaciniatum & $34 \pm 2$ & $22 \pm 2$ & 1.55 & Elliptical & Prolate & Tricolporate & Not distinct & Apocolpate & 30 & Acute & Granulate \\
\hline 8. S. lycopersicum & $\begin{array}{l}28.69 \pm \\
1.11 \\
\end{array}$ & $\begin{array}{l}13.26 \pm \\
1.74 \\
\end{array}$ & 2.16 & Elliptical & Perprolate & Tricolporate & Not distinct & Apocolpate & 24.35 & Acute & Psilate \\
\hline 9. S. macrocarpon & $\begin{array}{l}26.09 \pm \\
2.01\end{array}$ & $25 \pm 2$ & 1.04 & Circular & $\begin{array}{l}\text { Prolate- } \\
\text { spheroidal }\end{array}$ & Tricolporate & $4.35 \times 3.48$ & Syncolpate & 19.57 & Acute & Granulate \\
\hline 10. S. melongena & $\begin{array}{l}19.13 \pm \\
2.07\end{array}$ & $\begin{array}{l}15.22 \pm \\
2.18\end{array}$ & 1.26 & Circular & Sub-prolate & Tricolporate & $3.48 \times 1.3$ & Syncolpate & 15.87 & Obtuse & Granulate \\
\hline 11. S. nigrum & $\begin{array}{l}28.48 \pm \\
0.48\end{array}$ & $\begin{array}{l}17.61 \pm \\
0.59\end{array}$ & 1.62 & Trilobed & Prolate & Tricolporate & $2.39 \times 1.3$ & Apocolpate & 24.57 & Obtuse & Scabrate \\
\hline $\begin{array}{l}\text { 12. } S . \\
\text { schimperianum }\end{array}$ & $\begin{array}{l}26.09 \pm \\
1.09\end{array}$ & $\begin{array}{l}22.39 \pm \\
2.29\end{array}$ & 1.17 & Triangular & Sub-prolate & Tricolporate & $3.26 \times 4.35$ & Syncolpate & 22.61 & Obtuse & Granulate \\
\hline $\begin{array}{l}\text { 13. S. } \\
\text { seaforthianum }\end{array}$ & $15 \pm 0.50$ & $\begin{array}{l}15.16 \pm \\
1.46\end{array}$ & 0.99 & Trilobed & $\begin{array}{l}\text { Oblate- } \\
\text { spheroidal }\end{array}$ & Tricolporate & $4.69 \times 1.56$ & Syncolpate & 14.06 & Acute & Psilate \\
\hline 14. S. sinaicum & $\begin{array}{l}33.04 \pm \\
2.04\end{array}$ & $\begin{array}{l}15.65 \pm \\
1.35\end{array}$ & 2.11 & Elliptical & Perprolate & Tricolporate & Not distinct & Apocolpate & 28.26 & Acute & Psilate \\
\hline 15. S. umbellatum & $\begin{array}{l}20.65 \pm \\
1.35\end{array}$ & $\begin{array}{l}13.69 \pm \\
1.31\end{array}$ & 1.51 & Triangular & Prolate & Tricolporate & $2.17 \times 3.48$ & Apocolpate & 17.39 & Acute & Psilate \\
\hline 16. S. villosum & $\begin{array}{l}31.52 \pm \\
1.48\end{array}$ & $\begin{array}{l}16.52 \pm \\
1.48\end{array}$ & 1.91 & Elliptical & Prolate & Tricolporate & Not distinct & Apocolpate & 27.83 & Acute & Granulate \\
\hline
\end{tabular}

$\mathrm{PA}=$ Polar axis length, EA= Equatorial axis length, $\mathrm{P} / \mathrm{E}=$ Polar/Equatorial, $\mathrm{LxW}=$ Length $\mathrm{x}$ Width 


\section{Description of seed and pollen micromorphology}

\section{Identification Key based on palynological characters}

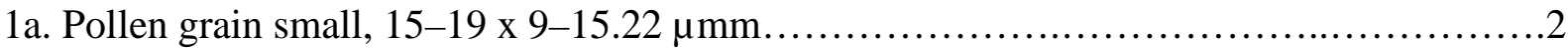

1b. Pollen grain large, 20.6 - 34 x 12-25

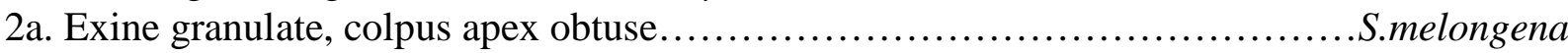

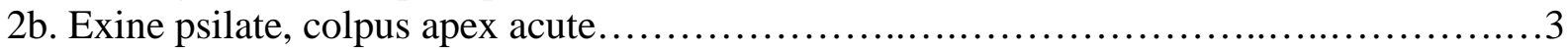

3a. Pollen grain prolate..................................................... diphyllum

3b. Pollen grains oblate-spheroid....................................... seaforthianum

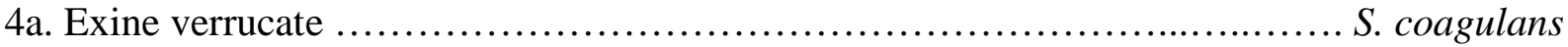

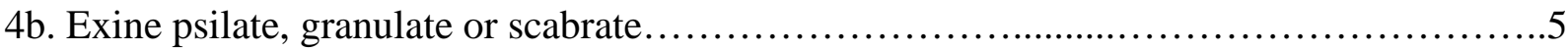

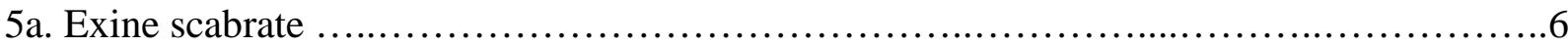

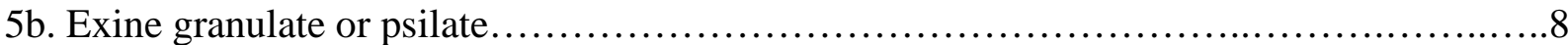

6a. Pollen grains spheroidal.................................................... incanum

6b. Pollen grains prolate ..............................................................

7a. Pollen grains 28.48 x $17.6 \mu \mathrm{mm}$; colpus apex obtuse......................... nigrum

7b. Pollen grains 20.63 x $12.03 \mu \mathrm{mm}$; colpus apex acute..........................S. abutiloides

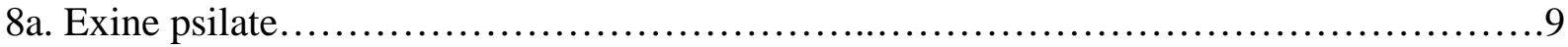

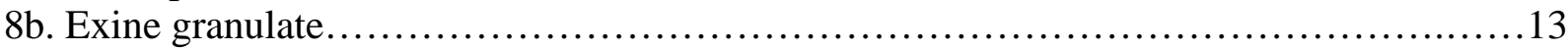

9a. Pollen grain 33.05 x $15.56 \mu \mathrm{mm}$; perprolate.................................. sinaicum

9b. Pollen grain 20.65 - 28.69 x $13.69-21.74 \mu \mathrm{mm}$; prolate- subprolate..................10

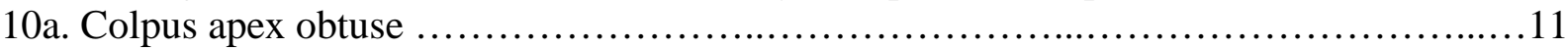

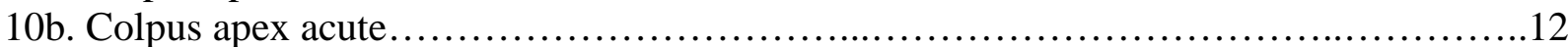

11a. Grains circular in equatorial view ............................................. forskalii

11b. Grains broadly elliptic in equatorial view.............................. S. elaeagnifolium

12a. Pollen grains perprolate.............................................. lycopersicum

12b. Pollen grains prolate ................................................... umbellatum

13a. Colpus apex obtuse........................................... S. schimperianum

13b. Colpus apex ocute............................................................

14a. Equatorial view circular; colpus short $19.57 \mu \mathrm{mm} . \ldots \ldots \ldots \ldots \ldots \ldots \ldots \ldots \ldots$. S. macrocarpon

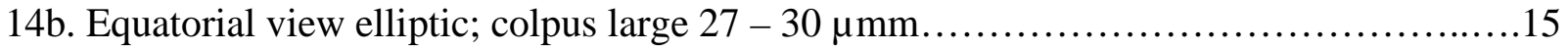

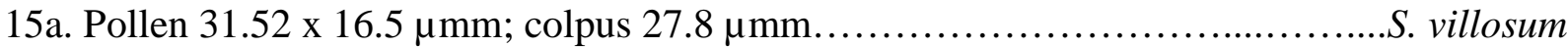

15b. Pollen 34 x $22 \mu \mathrm{mm}$; colpus $30 \mu \mathrm{mm}$....................................... laciniatum

\section{References}

Ahmed, S.M, and Fadl, M.A. (2016). Genetic relatedness among Solanum L. species assayed by seed morphology and isozyme markers. Pakistan Journal of Botany,48: 2011-2016.

Anderson, G.J. and Gensel, P.G. (1976). Pollen morphology and the systematics of Solanum section Basarthrum. Pollen \& Spores,18: 533-552.

Anil Kumar, V.S., Aswathy, P.J., Sunila, A.V. and Murugan, K. (2014). Characterisation of Solanum diphyllum L. A medicinally potential species from southern western Ghats in Kerala using SEM and FTIR spectroscopy. World Journal of Pharmacy and Pharmaceutical Sciences,3: 592-603.
Anil Kumar, V.S., Maya Nair, C. and Murugan, K. (2015). Pollen morphology of selected taxa of the genus Solanum from Southern Western Ghats, Kerala, India. Rheedea,25: 128-145.

Arora, A. and Modi, A. (2008). An acetolysis technique for pollen slide preparation. Indian Journal Aerobiology,21: 90-91.

Khafagy, A.A., El-Ghamery, A.A., Ghaly, O.N. and Ragab, O.G. (2018). Fruit and seed morphology of some species of Solanaceae. Taeckholmia,38: 123-140.

Bahadur, B. \& Farooqui, S.M. (1986). Seed and seed coat characters in Australian Nicotina, In: W.G. D’Arcy, (ed.), Solanaceae 
Biology and Systematics. New York, Columbia University Press. pp.: 114-137.

Barthlott, W. (1981). Epidermal and seed surface characters of plants: systematic applicability and some evolutionary aspects. Nordic Journal of Botany,1: 345-355.

Barthlott, W. (1984). Microstructural features of seed surface. In: V.H. Heywood and M. Moore (eds.), Current Concepts in Plant Taxonomy. Academic Press, London. pp.: 95105.

Bonnefill, P. \& Riollet, K., (1980). Pollens des savanes d'afrique arientale. Centre National de la Recherche Scientifique Paris.pp.:140.

Boulos, L. (2002). Flora of Egypt. vol. 3. Verbenaceae - Compositae. Al-Hadara Publishing, Cairo.

Bradley, D.E. (1960). The electron microscopy of pollen and spores. Grana Palynologica, 2: 38.

Carvalho, L. d'A.F., Machado, R.D. and Bovini, M.G. (1999). Seed coat micromorpholgy of Brazilian species of Schwenckia. In: M.H. Nee, D.E. Symon, R.N. Lester, and J.P. Jessop, (eds.), Solanaceae IV: Advances in Biology and Utilization. Kew, Royal Botanic, Gardens. pp.: 23-32.

Chakrabarti, A.K., Mukherjee, S.K., Maiti, G.G. and Kabi, M.C. (2003). SEM studies of seed and seed coat structures in cultivars of Lycopersicon esculentum Mill. Journal of vegetable Crop Production,9: 75-85.

Edmonds, J.M. (1983). Seed Coat Structure and Development in Solanum L. Section Solanum (Solanaceae). Botanical Journal of the Linnean Society,87: 229-246.

Edmonds, J.M. (1984). Pollen morphology of Solanum L., section Solanum. Botanical Journal of the Linnean Society, 88: 237-251.

El-Ghamery, A.A., Khafagi, A.F. and Ragab, O.G. (2018). Taxonomic implication of pollen morphology and seed protein electrophoresis of some species of Solanaceae in Egypt. Al Azhar Bulletin of Science,29(1): 43-54.

El-Ghazaly, G. (1993). A study on the pollen flora of Sudan. Review of Palaeobotany and Palynology,6 :99-345.

Erdtman, G. (1952). Pollen morphology and plant taxonomy. Angiosperms. Chronica Botanica Co., Waltham, Massachusettes.

Gbile, Z.O. and Sowunmi M.A. (1979). The pollen morphology of Nigerian Solanum species. In: J.G. Hawkes, R.N. Lester, A.D. Skelding, (eds.). The biology and Taxonomy of the Solanaceae. Academic Press, London. pp.: 335-342.

Ghimire, B., Ghimire, B.K. and Heo, K. (2011). Seed characteristics of Withania somnifera. Korean Journal of Plant Taxonomy, 41: 103-107.

Hepper, F.N. (1998). Family 159: Solanaceae in M.N. El-Hadidi (ed.) Flora of Egypt. Tackholmia Additional Series, 6:1-168.

Jennifer M.E. and James A.C. (1997). Black nightshades, Solanum nigrum L. and related species. International Plant Genetic Resources Institute IPGRI, Italy. pp.: 1-113.

Junlakitjawat, A., Thongpukdee, A. and Thepsithar, C. (2010). Seed coat micromorphology of some Solanum species in Thailand. Journal of the Microscopy Society of Thailand, 24: 13-16.

Lashin, G.M.A. (2011). Palynology of six species of Solanum (Solanaceae). Life Science Journal,8: 787-697.

Lashin, G.M.A. (2012). Ultra-structures and pollen morphology significance of some species of Solanum (Solanaceae). Egypt Journal of Botany. Special Issue. $2^{\text {nd }}$ Int. Bot. Conf. Minia University, 29-30 April, 2012. pp.: 141-156.

Lester, R.N. (1991). Evolutionary relationships of tomato, potato, pepino, and wild species of Lycopersicon and Solanum, in J.G. Hawkes, R.N. Lester, M. Nee, N. Estrada- 


\section{Description of seed and pollen micromorphology}

R (eds.), Solanaceae III: taxonomy, chemistry, evolution. London. pp.: 283-301.

Lester, R.N., Jaeger, P.M.L. and Child, A. (2011). Solanum in Africa. Birmingham, U. K. <www. Ru. Nl/ publish/ pages/ 677465/ rn/ Internet- version. pdf $>$

Lu, A. M. and Zhang, Z. Y. (1986). Studies of the subtribe Hyoscyaminae in China. in: W.G. D’Arcy, (ed.), Solanaceae: Biology and Systematics. New York, Columbia Universsity Press. pp.: 56-78.

Perveen, A. and Qaiser, M. (2007). Pollen morphology of family Solanaceae from Pakistan. Pakistan Journal of Botany,39(7): 2243-2256.

Punt, W., Hoen, P.P., Blackmore, S., Nilsson, S. and Le Thomas, A. (2007). Glossary of pollen and spore terminology. Review of Palaeobotany and Palynology,143: 1-81.
Sharma, B.D. (1974). Contribution to the palynotaxonomy of genus Solanum L. Journal of Palynology, 10: 51-68.

Singh, G. (2006). Plant Systematics, Theory and Practice, $2^{\text {nd }}$ Edition, Oxford and IBH Publishing Co. New Delhi.

Zhang, Z.Y and Lu, A.M. (1999). A comparative study of Physalis, Capsicum and Tubocapsicum, three genera of Solanaceae. In: M.H. Nee, D.E. Symon, and J.P. Jessop, (eds.), Solanaceae IV: Advances in biology and utilization. Royal Botanic Gardens, Kew. pp.: 81-96.

Zhang, Z.Y. and Wen, J. (1996). Characters of leaf epidermis and seed coats in Physalis (Solanaceae) from China and its systematic significance. Acta Botanica Yunnanuca, 18: 419-423.

Zhang, Z.Y., Yang, D.Z., Lu, A.M. and Knapp, S. (2005). Seed morphology of the tribe Hyoscyameae (Solanaceae). Taxon,54: 71-83 